\title{
Pengaruh Mebel Klasik dalam Interior Ruang Tamu Rumah Tinggal terhadap Pilihan Desain Mahasiswa Desain Interior
}

\author{
Riza Septriani Dewi \\ Program Studi Desain Interior, Fakultas Seni Rupa, Institut Seni Indonesia Yogyakarta \\ Email: riza.septriani@isi.ac.id
}

\begin{abstract}
Abstrak
Pilihan desain interior ruang tamu rumah tinggal sangat beraneka ragam karena manusia sebagai makhluk sosial, perilaku, sikap dan tindakannya selalu dipengaruhi baik oleh variable-variabel internal seperti motivasi dan persepsi maupun eksternal seperti pemilihan mebel klasik atau mebel modern, sehingga setiap individu memiliki seleranya masing-masing. Penelitian ini bertujuan untuk mengeksplorasi persepsi kenyamanan dan pengaruhnya terhadap pilihan desain mebel ruang tamu oleh penghuni di rumah tinggal. Penelitian ini menggunakan metode eksperimen stimulusresponse melalui pendekatan kuantitatif. Stimulus eksperimen yang digunakan berupa simulasi gambar digital interior ruang tamu rumah tinggal dalam 3 kondisi guna mendapatkan respon persepsi dan sikap. Data hasil eksperimen dianalisis menggunakan ANOVA, menunjukkan bahwa (1) penggunaan mebel klasik Indonesia yang paling mempengaruhi persepsi dan pilihan desain responden; (2) ditemukan juga hubungan antara persepsi dan sikap kaitannya dengan proses persepsi dapat membangkitkan emosi dan mempengaruhi sikap responden, hal ini sejalan dengan mekanisme persepsi dimana kontribusi mebel klasik dapat mempengaruhi persepsi dan munculnya sikap responden di ruang tamu rumah tinggal.
\end{abstract}

Kata kunci: mebel klasik, ruang tamu, persepsi, pilihan desain

\begin{abstract}
The selection of interior design for the living room of the residence is very diverse because humans as social beings, their behavior, attitudes and actions are always influenced by internal variables such as motivation and perception as well as external such as the selection of classic furniture or modern furniture, so that each individual has their own taste. This study was aimed at exploring perceptions of comfort and its effect on the selection of living room furniture design by residents in residential. In the experiment for this study, a stimulus-response method was applied, using a quantitative approach based. Simulated digital images of a living room interior in 3 conditions to get perception, and attitude responses. The data of this research were analyzed by ANOVA and showed that: (1) the use of Indonesia's most classic furniture and design choices affect the perception of the respondents;(2) a link was found between perceptions and attitudes is related to perception process that can influence consumer attitudes, in line with the mechanism of perception where the contribution of classical furniture can influence respondents perception and attitudes in the living room of the residence.
\end{abstract}

Keywords: classic furniture, living room, perception, design selection.

\section{Pendahuluan}

Pemilihan desain interior misalnya desain ruang tamu sangat beraneka ragam karena manusia sebagai makhluk sosial, perilaku, sikap dan tindakannya selalu dipengaruhi baik oleh variablevariabel internal seperti motivasi dan persepsi maupun eksternal seperti pemilihan mebel klasik atau mebel modern, sehingga setiap individu memiliki seleranya masing-masing. Ruang Tamu 
memiliki peran penting dalam sebuah hunian. Tidak hanya sebagai tempat interaksi sosial dengan orang lain, area yang biasanya terletak pada bagian depan rumah ini juga merupakan wadah untuk menunjukkan jati diri dan status sosial pemiliknya. Purnamasari (Lathiyfah, Antariksa, \& Noviani , 2010) menjelaskan bahwa penyebab perubahan pola tata ruang dalam pada rumah tinggal kolonial di Kidul Dalem yaitu kebutuhan dasar manusia, kebutuhan identitas diri, perubahan gaya hidup, teknologi baru, faktor ekonomi dan faktor politik yang membuat penambahan ruang, perluasan ruang, pembagian ruang, dan perubahan fungsi pada ruang. Sedangkan Aji (Aji, 2008) menjelaskan bahwa ruang tamu di Indonesia memiliki posisi yang unik dibandingkan ruang lainnya dan mengungkap makna interior ruang tamu di lima kelompok sosial yang berbeda dapat mempengaruhi pilihan desain sebuah ruang tamu. Rechavi (Rechavi, 2009) mengungkapkan bahwa benda-benda di ruang tamu dapat menyimpan makna pribadi yang mendalam. Estetika dan kerahasiaan adalah kriteria yang menentukan inklusi di ruang tamu, tetapi bukan atribut yang paling relevan, sementara objek yang tidak dianggap menarik secara estetika sering ditempatkan di kamar selain ruang tamu.

Ruang tamu memang memiliki makna pribadi yang kaya bagi para penghuninya. Orang yang sering bepergian (traveling) akan memajang semua suvenir dari setiap tempat yang pernah didatanginya di ruang tamu tanpa memikirkan itu cocok atau tidak dengan tata ruangnya. Ada juga orang-orang yang masih menganut unsur-unsur budaya induknya juga dapat tercermin pada ruang tamu. Sebagian orang yang menggunakan jasa desainer pun dapat menghalangi sirkulasi ruang tamu tersebut dengan semua koleksi yang ingin diperlihatkannya. Dan juga masih ada orang yang bisa menyatukan semua keinginannya dan desain ruang tamu dengan baik tanpa merusak fungsi dan estetika ruang tersebut. Itu semua karena setiap orang memiliki pilihan desain sendiri yang mungkin dipengaruhi oleh beberapa aspek yang terkait dengan psikologi seperti persepsi. Persepsi adalah proses dimana seseorang memperoleh informasi dari lingkungan atau ruang interior yang dimasukinya. Karenanya persepsi menjadi suatu aspek dari interaksi yang bersifat aktif dan memerlukan pertemuan nyata dengan suatu obyek, juga persepsi membutuhkan proses kognisi serta afeksi sebagai satu kesatuan dalam sistem kepribadian (Hidjaz, 2011).

Sedangkan disisi lain pada kenyataannya, pemilihan desain mebel klasik atau mebel modern merupakan variabel yang berinteraksi dengan ruang interior, sehingga menimbulkan kesan, pengalaman dan makna tersendiri atau tertentu bagi seseorang misalnya ketika memasuki suatu ruangan khususnya ruang tamu. Klasik dalam penelitian ini adalah kategori mebel-mebel lampau, melewati kurun waktu yang lama dan diterima penggunanya hingga saat ini. Mebel-mebel yang mencapai kedewasaan seni atau yang mencapai tingkat kematangan (maturity) secara seni, hingga tidak bisa ditambah atau dikurangi lagi dalam pengembangan desainnya. Berdasarkan data Pusdatin Kemenperin tahun 2020, menjelaskan bahwa geliat ekspor furnitur di wilayah Jawa Timur ditunjukan dari nilai ekspor olahan kayu dan furnitur pada bulan Januari sebesar 146,21 Juta dolar AS. Pada bulan Februari dan Maret, nilai ekspor naik secara berturut-turut sebesar 155,06 Juta dolar AS dan 161,92 Juta dolar AS. Data Badan Pusat Statistik (BPS) Jatim 2020, total kontribusinya sebesar 2,89\% dengan pertumbuhan relatif tinggi sebesar 9,73\% di tahun 2019 , angka tersebut meningkat dari tahun 2018 senilai 7,62\%. (4amri, 2020). Menurut Purnomo (Purnomo, Irawati, \& Melati, 2010) Jepara diperkirakan menyumbang sekitar 10\% dari total ekspor mebel Indonesia berdasarkan data dari Dinas Perindustrian dan Perdagangan Jepara tahun 2009. Di dalam penelitian sebelumnya (Chen, Yeh, \& Huan, 2014) mengungkapkan restoran di Taiwan didekorasi dengan barang antik masa penjajahan Taiwan dan disimulasikan kepada konsumen usia muda (tidak pernah mengalami masa tersebut secara langsung) memberi dampak positif terhadap pengalaman konsumen.

Pambudi (Pambudi, 2017) mengungkapkan tentang tata letak dan pemilihan furnitur di ruang tamu pada empat rumah tinggal abdi dalem Keraton Yogyakarta yaitu dengan cara memajang foto keluarga, memajang identitas profesi sebagai abdi dalem, dan memilih kursi bergaya klasik yang merupakan salah satu kebanggaannya. Rahma (Rahma, 2017) juga mengungkapkan bahwa elemen interior berupa elemen dekoratif dan mebel klasik paling efektif membangkitkan pengalaman nostalgia yang mempengaruhi sikap berkunjung kembali konsumen ke restoran dibandingkan 
dengan gaya modern. Dan Goulding dalam Rutherford (Rutherford \& Shaw, 2011) mengungkapkan bahwa mengeksplorasi pengalaman masa lalu dengan reaksi nostalgia dan estetika konsumsi kepada konsumen usia 22-40 tahun, menjadi motif membeli yang kuat dalam perilaku konsumsi. Ini menunjukkan bahwa mebel klasik atau mebel lawas masih menjadi pilihan desain masyarakat Indonesia. Namun sejauh ini belum diketahui atau belum ada penelitian yang terkait dengan pengaruh mebel klasik dalam interior ruang tamu rumah tinggal terhadap pilihan desain. Hal itu mendorong peneliti untuk lebih jauh mengkaji korelasi dan dampak (apakah) ada perbedaan pengaruh stimulus ruang tamu klasik dengan ruang tamu modern terhadap pilihan desain seseorang.

Penelitian ini berusaha untuk mengungkapkan apakah mebel klasik mempengaruhi persepsi seseorang dalam menentukan pilihan desain khususnya desain interior ruang tamu pada rumah tinggal. Diharapkan hasil penelitian ini dapat menjadi rekomendasi bagi perkembangan ilmu desain serta memberikan sumbangan pemikiran terhadap perancangan desain interior yang sesuai dengan keinginan klien. Berdasarkan gambaran diatas maka yang menjadi masalah dalam penelitian ini adalah apakah persepsi mempengaruhi pilihan desain.

\section{Mebel di Ruang Tamu}

Ruang tamu merupakan ruang pertama yang dapat diakses para tamu dan bersifat terbuka dibanding ruang lainnya di rumah tinggal. Karakter penataan di ruang tamu akan mencerminkan karakter sang penghuni. Oleh karena itu ruang tamu harus ditata dengan menarik untuk memberikan kesan yang baik. Menurut Aji (Aji, 2008) Ruang tamu adalah ruang yang berfungsi untuk menerima tamu baik yang telah dikenal maupun tidak dikenal, ruang tamu pada umumnya terletak pada bagian depan rumah. Purnomo (Purnomo, Irawati, \& Melati, 2010) mengungkapkan bahwa ruang tamu atau ruang duduk tamu merupakan ruang yang diletakkan di bagian depan rumah yang diibaratkan sebagai wajah dari keseluruhan ruang pada rumah tinggal sebagai tubuhnya. Sedangkan mebel merupakan unsur unik karena mebel itu sendiri adalah dekorasi yang kehadirannya di dalam ruang terbawa oleh fungsi. Furnitur/mebel sebagai variable tak bergantung dari ruang dapat mempengaruhi persepsi dan penilaian orang terhadap ukuran ruang. Menurut Suptandar dalam (Trumansyahjaya, 2015) kebutuhan yang berbeda-beda dalam satu ruang hendaknya disesuaikan dengan selera orang yang akan memakai tanpa mengesampingkan fungsi furnitur. Adapun kebutuhan mebel dan aksesoris diruang tamu menurut Sandjaya (2003: 12) yaitu : Satu sofa double seater, dua atau lebih kursi tunggal, meja tamu / coffee table, meja sudut, lampu, karpet dan satu atau dua hiasan dinding.

\section{Mebel Klasik di Ruang Tamu Indonesia}

Konsep klasik merupakan konsep interior yang berasal dari gaya Romawi dan Yunani yang berbasis pada susunan, keseimbangan dan harmonisasi yang sempurna Wicaksono (Wicaksono \& Tisnawati, 2014). Desain klasik tidak termasuk elemen modern dan pengaruh yang terjadi saat ini tapi berangkat dari tradisi. Klasik dalam penelitian ini adalah kategori mebel-mebel lampau (lawas/jadul), melewati kurun waktu yang lama dan masih diterima penggunanya hingga saat ini. Mebel-mebel yang mencapai kedewasaan seni atau yang mencapai tingkat kematangan (maturity) secara seni, hingga tidak bisa ditambah atau dikurangi lagi dalam pengembangan desainnya. Berdasarkan hasil wawancara narasumber, desain klasik pada ruang tamu hunian di Indonesia dibedakan menjadi dua yaitu klasik Indonesia dan klasik Barat/Eropa. Klasik Indonesia memiliki karakter : lantai ubin dan karpet island, dinding dengan ukiran (gebyok), jendela memakai fitrase, plafon eternit dengan permainan drop/up ceiling, Sebagian lagi dari kayu, bentuk jengki dan rounded, mebel tidak memakai ukiran seperti kursi jengki dan sedanan, lemari prongkas, adopsi gaya Art Deco, material kayu dipelitur, rotan dengan warna coklat tua atau tea brown dan mengikuti arsitektur jengki dan Art Deco Streamline.

Sedangkan desain klasik Barat/Eropa menurut masyarakat Indonesia memiliki karakter: lantai granit, marmer dan wall-to-wall karpet, karpet island, dinding wallpaper, kombinasi list kayu, 
jendela memakai gorden, plafon eternit polos dengan list kayu, bentuk rounded, mewah dan meliuk-liuk, mebel berukuran besar, dudukan kursi tebal, bermotif, dari kain atau kulit dan memiliki ukiran, material kayu yang dibubut, fabric, upholstery, dan kulit, serta mengacu pada era louis XV.

\section{Mebel Modern di Ruang Tamu Indonesia}

Konsep modern berawal dari semangat minimalisme yang mengarah pada fungsionalitas sebuah ruangan (Wicaksono \& Tisnawati, 2014). Desain modern lebih mengutamakan fungsi dan efektivitas penggunaan sehingga berdampak pada desain yang hampir tidak menggunakan ornamen hiasan. Mebel ruang tamu modern pada penelitian ini mengambil idiom pendapat Kunjoroningrat dalam Wukir (Wukir \& Sugiyanto, 2010), modern di Indonesia dikategorikan atas: karya desain yang diciptakan sebagai tuntutan masyarakat yang berpikiran modern, baik secara mentalitas maupun tindakannya dan karya desain yang mengadatasi dan menggunakan unsur kebudayaan barat yang telah modern tanpa harus 'menjadi Barat' atau 'berdiri Barat'. Berdasarkan hasil wawancara dengan narasumber, desain modern pada ruang tamu hunian di Indonesia memiliki karakter: lantai keramik, parket, karpet island motif sederhana, dinding polos bermain dengan warna, plafon permainan drop/up ceiling, dan permainan cahaya, bentuk geometri murni, tidak ada ukiran, sleek, fabrikasi, dirangkai ditempat, mebel tidak memakai ukiran, dudukan dan sandaran kusi dibungkus busa dengan rangka kayu atau rotan, material besi, kayu, mengacu pada era tahun 80an-90an.

\section{Perilaku manusia mempersepsi lingkungan}

Desain interior sebuah ruang dikatakan berhasil ketika interaksi manusia dengan elemen pembentuk ruang itu berjalan dengan baik sehingga timbul rasa nyaman. Kenyamanan itu merupakan kondisi batiniah pada manusia yang tercipta dari stimulus yang diterima oleh inderawi karena elemen-elemen ruang tersebut merangsang manusia dan tidak ditolak kehadirannya (Dewi, 2013). Pengaruh ruang tamu terhadap perilaku penggunanya cukup jelas karena pengguna melakukan kegiatan seperti menjamu tamu dan berkumpul dengan keluarga di ruang tersebut sehingga diharapkan mempunyai bentuk, mebel dan kondisi yang sesuai dengan karakter penghuninya. Timbulnya minat memilih desain di ruang tamu disebabkan adanya niat yang erat kaitannya dengan persepsi, motivasi dan perilaku pengguna.

Penggunaan mebel klasik pada interior ruang berkontribusi pada pengalaman masa lalu dalam proses persepsi. Persepsi itu akan mempengaruhi kognisi yang memungkinkan terjadinya motivasi, sikap dan perilaku menurut Budiarti dalam Rahma (Rahma, 2017). Sedangkan minat adalah dasar dari motivasi. Goulding dalam Rutherford (Rutherford \& Shaw, 2011)mengeksplorasi pengalaman masa lalu dengan reaksi nostalgia dan estetika konsumsi kepada konsumen usia 22-40 tahun, motif membeli konsumen terpengaruh oleh faktor story telling yang berulang tentang objek yang pernah ada 10-15 tahun yang lalu, tidak senang dengan gaya dan desain estetika saat ini, pengalaman sosial dan jenis produk yang lebih tahan lama menjadi motif membeli yang kuat dalam perilaku konsumsi. Deci \& Ryan dalam Dewi membuktikan bahwa ketika konsumen termotivasi, mereka akan merasakan minat dan kesenangan, lalu mereka mempersepsikannya secara internal yang terlihat langsung dari perilaku mereka berupa sikap. Sikap seseorang seperti membeli ataupun memilih desain dapat dipicu dengan cara memancing memori masa lalu berupa refleksi emosi seseorang sehingga mempengaruhi keputusannya (Rutherford \& Shaw, 2011). Proses tersebut dapat digambarkan sebagai berikut : 


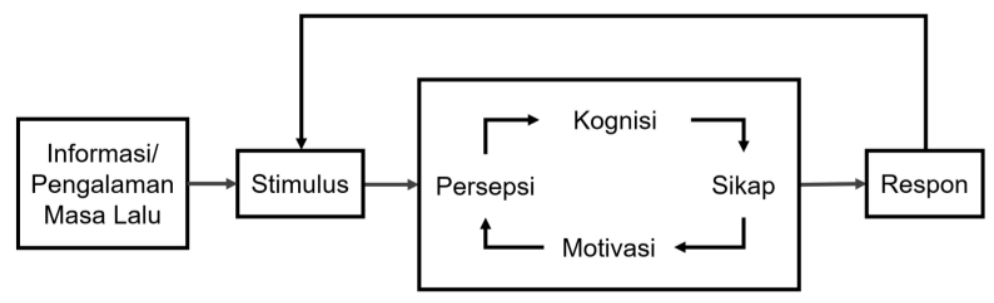

Diagram 1 Mekanisme Persepsi

(Sumber : Pribadi, 2020)

Informasi atau pengalaman masa lalu akan memberikan stimulus dan mempengaruhi kognisi (alam pikiran) yang memungkinkan terjadinya persepsi, motivasi dan terbentuknya sikap dan selanjutnya mempengaruhi perilaku yang muncul. Pendapat lain mengungkapkan bahwa persepsi merupakan elemen kognitif yang merupakan 'landasan awal' dan dapat mempengaruhi seseorang dalam bertindak. Meskipun memang tidak ada jaminan bahwa bila seseorang berpersepsi positif maka akan bertindak positif pula akhirnya, namun setidaknya persepsi merupakan pembuka yang memberikan makna bagi suatu gejala dan turut memberikan andil bagi terbentuknya perilaku tertentu. Persepsi visual yang tercipta bisa dipengaruhi oleh pengaturan tata letak, pemilihan mebel atau unsur ruang lain yang mempengaruhi persepsi bentuk. Di dalam rumah tinggal seperti ruang tamu, perilaku pengguna terikat pada faktor budaya, pendidikan, pekerjaan, status dan kebutuhan biologis atau pencerminan kepribadian yang menjadi bagian proses dalam pemilihan desain untuk memenuhi kebutuhan psikologis dan sosiologisnya. Kebutuhan psikologis dan sosiologis tercermin dari kenyamanan privasi yang terlihat dalam rumah tinggal tersebut. Sedangkan faktor budaya terdiri dari tren dan persepsi, nilai-nilai dan norma, kebiasaan serta perilaku kelompok masyarakat . Dari mekanisme persepsi tersebut terciptalah instrumen-instrumen sikap yang memperkuat teori persepsi dan penelitian sebelumnya dalam pilihan desain mahasiswa desain interior, yaitu berupa aktivitas berlama-lama, ketertarikan pada mebel, membeli mebel, mempromosikannya, memilih desain meski tidak tren, memilih desain karena mudah dibuat dan mudah ditemukan.

\section{Metode}

Penelitian ini menggunakan metode eksploratori deskriptif dan eksperimen, melalui pendekatan statistika dengan sifat analisis kuantitatif. Eksploratori dilakukan untuk menggali data dan informasi yang kemudian dipaparkan secara deskriptif melalui tahapan wawancara kepada pengusaha dibidang mebel dan peneliti yang meneliti tentang mebel. Hasil tahap wawancara menunjukkan bahwa kursi jengki dan kursi sedanan dengan kaki kecil ke bawah tanpa ukiran melambangkan mebel klasik Indonesia. Sedangkan sofa, kursi dan meja dengan ukiran bergaya era Louis XV, menggunakan upholstery tebal bermotif flora melambangkan mebel klasik Barat/Eropa yang popular di rumah tinggal Indonesia. Dan sofa dengan rangka kayu yang dibungkus upholstery warna motif polos pada dudukan dan sandarannya, meja yang berwarna melambangkan mebel modern yang populer di rumah tinggal Indonesia. Dari hasil tahap eksploratori tersebut dijadikan acuan dalam pembuatan model 3D ruang tamu sebagai stimulus dari penelitian.

Stimulus eksperimen yang digunakan dalam penelitian ini merupakan simulasi visual dalam bentuk gambar digital dari sebuah ruang tamu rumah tinggal yang menggunakan konsep klasik dan modern, yang dapat dilihat dalam bentuk layar. Kemudian stimulus eksperimen tersebut digunakan untuk mengukur respon persepsi dan sikap dari responden. Sedangkan pengolahan data riset dalam penelitian tersebut menggunakan statistik ANOVA dengan bantuan SPSS.

Variabel yang diujikan kepada responden dalam penelitian ini, menggunakan rancangan penelitian within subject design. Within subject design adalah tipe desain eksperimental yang dilakukan dengan mengelompokkan responden yang terdiri dari 111 responden merupakan pria dan wanita 
dengan rentang usia 18-22 tahun (dewasa muda) yang merupakan kaum milineal, berprofesi sebagai mahasiswa desain interior dan dibagi menjadi 3 grup. Responden mengevaluasi setiap kondisi stimulus sebanyak 3 kondisi. Tipe ini digunakan untuk mendeskripsikan perbedaan kombinasi variabel bebas dan terikat yang diujikan dengan pelaksanaan eksperimen dapat dilakukan di hari yang sama. Variabel bebas (independent variable) adalah: kondisi 1 (ruang tamu klasik Indonesia), kondisi 2 (ruang tamu klasik Barat/Eropa), dan kondisi 3 (ruang tamu Modern). Variabel terikat (dependent), yaitu persepsi nyaman dan sikap pilihan desain dari responden, yang pertanyaannya disiapkan dalam bentuk kuesioner. Setiap kelompok responden akan diarahkan kepada semua level kondisi yang berbeda yaitu: kelompok responden 1 menilai kondisi 1 , kelompok responden 2 menilai kondisi 2, dan kelompok responden 3 menilai kondisi 3, untuk mendapatkan hasil yang ideal dan tidak bias. Melalui eksperimen ini, respon sikap responden yang terdiri dari komponen kognitif dan afektif, akan diukur melalui kuisioner. Dengan cara eksperimen, minat memilih desain akan dilihat dari respon sikap terhadap ruang tamu yang menerapkan konsep berbeda-beda (klasik dan modern) diharapkan dapat diidentifikasi, karena dalam eksperimen ini, konsep klasik dan modern dengan setting desain yang sengaja diciptakan dapat dikendalikan. Jadi responden akan merespon beberapa kondisi variabel tersebut dan datanya akan dibandingkan satu sama lain dengan tujuan menjawab pertanyaan riset.

Stimulus eksperimen yang digunakan dalam penelitian ini merupakan model berupa simulasi gambar yang dibuat dengan menggunakan 3D software SketchUp 2017 untuk modelling dan dirender menggunakan program plug-in- render engine Vray for SketchUp 2017 sebagai penyelesaian. (Lihat Gambar 1).

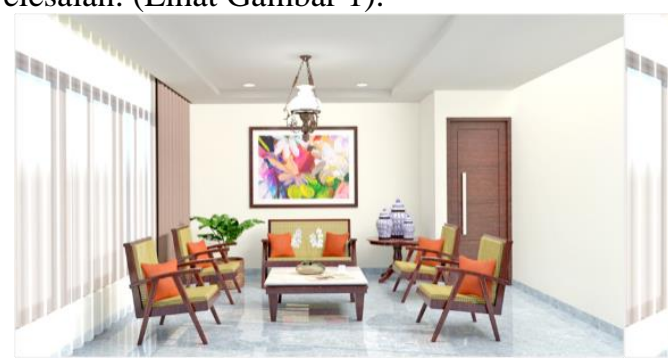

Kondisi 1

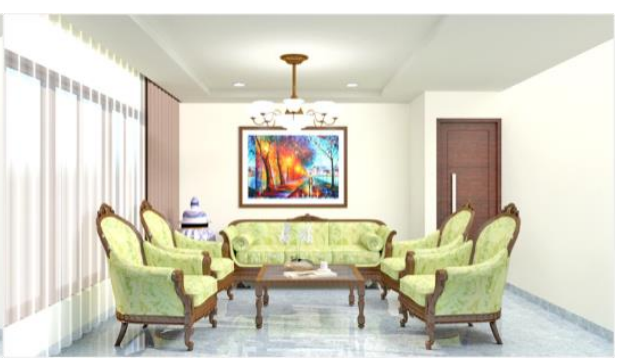

Kondisi 2

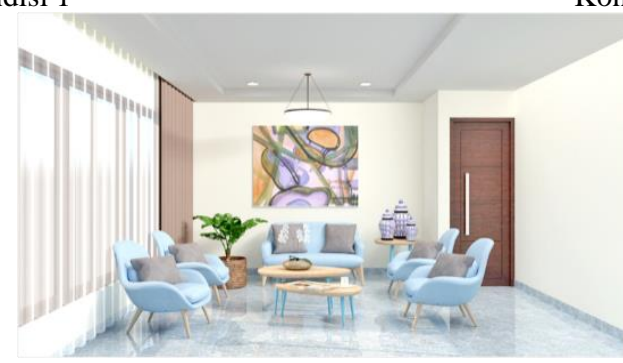

Kondisi 3

Gambar 1 Kondisi 1, desain ruang tamu klasik indonesia 2, desain kondisi 2 ruang tamu klasik barat/eropa 3, kondisi 3 desain ruang tamu modern

(Sumber : Pribadi, 2020)

Eksperimen ini dilakukan melalui dua tahap yaitu tahap uji eksperimen (pilot test) dan eksperimen utama untuk mendapatkan hasil yang akurat. Tahap uji coba dilakukan untuk mengukur tingkat validitas, realibitas instrumen eksperimen melalui uji statistik Cronbach Alpha. Setelah melakukan tahap uji coba, baru dilakukan tahap eksperimen utama. Pelaksanaan eksperimen dilakukan dengan mengelompokkan responden yang terdiri dari 37 orang. Responden mengevaluasi setiap kondisi stimulus sebanyak 3 kondisi, metode ini disebut sebagai Within Subject Design. Responden mengevaluasi kondisi dengan urutan pengisian dimulai dari kuesioner 1 (persepsi) - kuesioner 2 (sikap). Responden akan mengisi kuesioner yang berisi pertanyaan tentang persepsi berupa tabel menggunakan semantic differential scale dengan tujuh skala nilai pengukuran yang terdiri dari 8 
persepsi dan skala Likert untuk mendapatkan respon sikap yang terdiri dari 15 sikap. Nilai skor yang tinggi akan menunjukkan sikap yang lebih positif dari pada nilai skor yang rendah.

\begin{tabular}{|c|c|c|c|c|c|c|c|c|}
\hline \multirow[b]{2}{*}{$(+)$} & \multicolumn{8}{|c|}{ Persepsi } \\
\hline & 7 & 6 & 5 & 4 & 3 & 2 & 1 & $(-)$ \\
\hline hangat & & & & & & & & dingin \\
\hline akrab & & & & & & & & tidak akrab \\
\hline harmoni & & & & & & & & berantakan \\
\hline damai & & & & & & & & bergejolak \\
\hline sederhana & & & & & & & & menyolok \\
\hline nyaman & & & & & & & & tidak nyaman \\
\hline abadi & & & & & & & & sementara \\
\hline familiar & & & & & & & & asing \\
\hline
\end{tabular}

Tabel 2 Tabel Skala Sikap yang Digunakan dalam Kuesioner

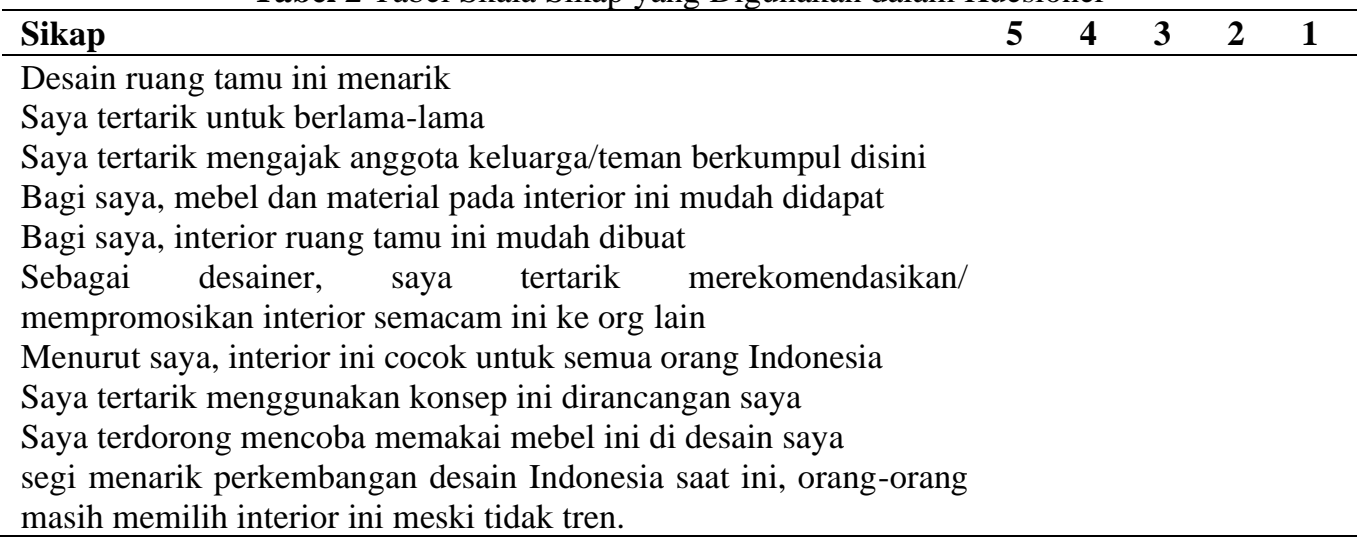

\section{Pembahasan}

Hasil test ANOVA menunjukkan bahwa perubahan ketiga kondisi memiliki rata-rata nilai sama. Menimbulkan persepsi nyaman dengan nilai (Sig. $=0.711, \mathrm{~F}=34.3$ ) dan sikap positif dalam pilihan desain $($ Sig. $=0.809, \mathrm{~F}=21.2)$.

\section{Analisis Respon Persepsi}

Hasil test Mauchly's Test of Sphericity untuk respon persepsi menunjukkan bahwa kombinasi ketiga kondisi ruang tamu dapat diterima dengan nilai signifikan $>0.005$ yaitu 0.240.

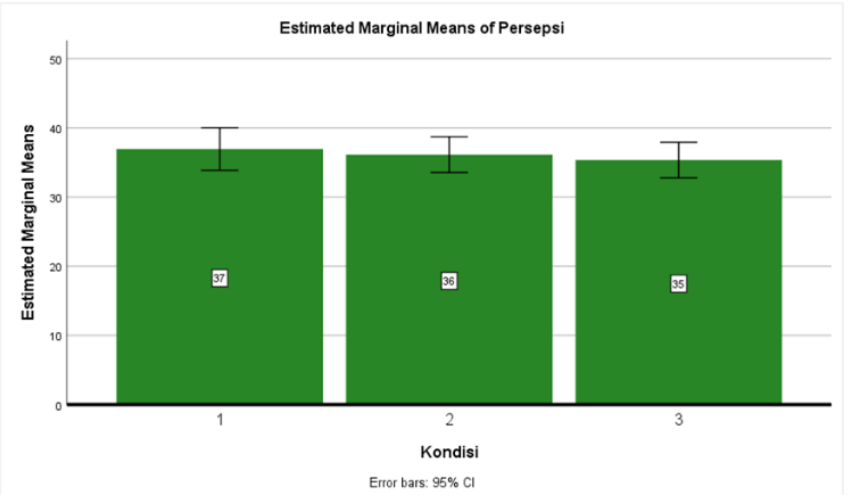

Gambar 2 Grafik hasil perhitungan Persepsi antar kondisi 
Dari analisis data untuk item pertanyaan tentang persepsi, diperoleh hasil antara lain:

1. Pada pengukuran respon psikologis persepsi diatas, jumlah skor yang tinggi menunjukkan persepsi yang lebih positif dari pada nilai skor yang rendah. Disimpulkan bahwa responden menilai kondisi 1 yang memiliki nilai lebih positif terhadap persepsi yaitu ruang tamu yang menggunakan mebel klasik Indonesia.

2. Persepsi 1 (kelompok 1 menilai kondisi 1) dengan nilai rata-rata 37, persepsi 2 (kelompok 2 menilai kondisi 2) dengan nilai rata-rata 36 dan persepsi 3 (kelompok 3 menilai kondisi 3) dengan nilai rata-rata 35 .

3. Kondisi yang dipersepsikan paling dapat membangkitkan respon persepsi adalah kondisi 1 yaitu ruang tamu yang menggunakan mebel Klasik Indonesia, diikuti oleh kondisi 2 yaitu ruang tamu Klasik Barat/Eropa dan terakhir adalah ruang tamu Modern.

4. Kondisi 1 dinilai lebih tinggi dibanding kondisi 2 dan 3, namun tidak berbeda jauh. Hal ini diduga faktor usia responden yang berkisar 18-22 tahun belum mengalami langsung gaya klasik Indonesia dan sudah berinteraksi langsung dengan gaya modern.Bagian pembahasan dapat dibagi dalam beberapa sub bagian yang pada pokoknya merupakan pelaksanaan dari proses dan metode yang telah ditulis pada bab sebelumnya. Pembahasan tentang tinjauan pustaka tidak perlu dibuatkan bab tersendiri, tinjauan pustaka sebaiknya ditulis menyatu dalam bab pembahasan.

\section{Analisis Respon Sikap}

Hasil test Mauchly's Test of Sphericity untuk respon sikap menunjukkan bahwa kombinasi ketiga kondisi ruang tamu dapat diterima dengan nilai signifikan $>0.005$ yaitu 0.417 .

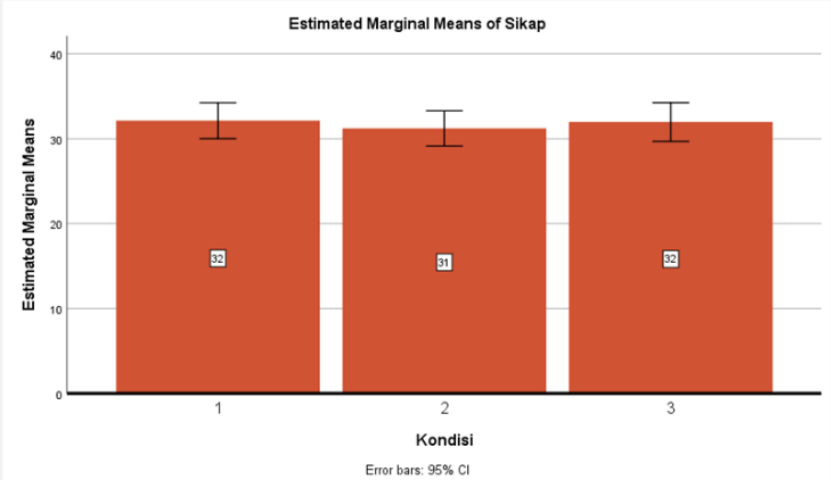

Gambar 3 Grafik hasil perhitungan Sikap antar kondisi

Dari analisis data untuk item pertanyaan tentang Sikap, diperoleh hasil antara lain:

1. Pada pengukuran respon psikologi Sikap diatas, disimpulkan bahwa terlihat perbedaan yang tidak terpaut jauh pada emosi responden dan menilai kondisi 1 yang memiliki nilai lebih positif terhadap sikap yaitu ruang tamu yang menggunakan mebel klasik Indonesia pada elemen interiornya.

2. Sikap 1 (kelompok 1 menilai kondisi 1) dengan nilai rata-rata 32 (32.135), sikap 2 (kelompok 2 menilai kondisi 2) dengan nilai rata-rata 31 dan sikap 3 (kelompok 3 menilai kondisi 3) dengan nilai rata-rata $32(31.973)$.

3. Kondisi yang memiliki emosi yang paling dapat membangkitkan respon Sikap adalah kondisi 1 yaitu ruang tamu yang menggunakan mebel Klasik Indonesia, diikuti oleh kondisi 3 yaitu ruang tamu ruang tamu Modern dan kondisi 2 yaitu ruang tamu Klasik Barat/Eropa.

4. Kondisi 1 juga dinilai lebih tinggi dibanding kondisi 2 dan 3, namun tidak berbeda jauh pada pilihan desain responden. Hal ini diduga faktor usia responden yang berkisar 18-22 tahun belum mengalami langsung gaya klasik Indonesia dan sudah berinteraksi langsung dengan gaya modern. 


\section{Analisis Respon Sikap}

Berikut hasil uji korelasi Pearson untuk mengetahui apakah terdapat hubungan antara respon persepsi dan respon Sikap Pilihan Desain. pada table 3 menunjukkan hasil uji korelasi 0.706 pada persepsi dan 0.706 pada sikap, maka dapat dikatakan bahwa antara persepsi dan sikap memiliki tingkat korelasi yang kuat atau memiliki korelasi dengan arah yang positif.

Tabel 3 Tabel Skala Sikap

\begin{tabular}{|c|c|c|c|}
\hline \multicolumn{4}{|c|}{ Correlations } \\
\hline & & Persepsi & Sikap \\
\hline \multirow[t]{3}{*}{ Persepsi } & Pearson Correlation & 1 & $.706^{\prime \prime}$ \\
\hline & Sig. (2-tailed) & & .000 \\
\hline & $\mathrm{N}$ & 111 & 111 \\
\hline \multirow[t]{3}{*}{ Sikap } & Pearson Correlation & $.706^{*}$ & 1 \\
\hline & Sig. (2-tailed) & .000 & \\
\hline & $\mathrm{N}$ & 111 & 111 \\
\hline
\end{tabular}

\section{Simpulan}

Berdasarkan hasil eksperimen persepsi terhadap mebel, kelompok eksperimen yang mempunyai rata-rata persepsi yang lebih positif adalah kondisi 1 (Mebel Klasik Indonesia). Variabel mebel klasik Eropa/Barat dan mebel Modern tidak terlalu menimbulkan respon konsumen yang signifikan terhadap peningkatan persepsi tetapi tetap mendapat respon yang positif. Variabel ruang tamu klasik Indonesia ini berkaitan dengan seberapa besar pengaruh mebel klasik Indonesia terhadap persepsi responden. Pada penelitian ini, mebel klasik Indonesia terbukti memberikan pengaruh terhadap persepsi desain responden dibandingkan mebel Klasik Eropa/Barat dan Mebel Modern dan menjawab pertanyaan penelitian pertama. Sedangkan untuk hasil respon Sikap, disimpulkan bahwa responden menilai kondisi 1 hampir sama dengan kondisi 3 karena terjadi pembulatan nominal angka dan kondisi 1 yang memiliki nilai lebih positif terhadap sikap pilihan desain. Hal ini sekaligus menjawab pertanyaan penelitian kedua.

Yang menarik dari hasil eksperimen ini, meski ada dua kondisi klasik dalam penelitian, yaitu ruang tamu Klasik Indonesia dan ruang tamu Klasik Eropa/Barat, responden lebih memberi respon positif terhadap ruang tamu Klasik Indonesia. Peneliti menyimpulkan bahwa "Variabel mebel Klasik Indonesia memiliki pengaruh terhadap persepsi dan sikap berupa minat pada pilihan desain responden". Ada kolerasi yang langsung antara mebel klasik yang merupakan relasi positif dengan sikap untuk memilih desain dan membuktikan asumsi peneliti serta menjawab pertanyaan penilitian. Menelaah model teori kongnisi lingkungan Gold, lingkungan pada ruang tamu adalah variabel bebas berupa mebel, berpengaruh terhadap intensitas emosi pada responden dan menegaskan bahwa persepsi lingkungan seseorang tidak saja bersifat subjektif tetapi juga dinamis. Selanjutnya persepsi ini berdampak pada respon perilaku pengguna yaitu memilih desain klasik. Serta model mekanisme persepsi yaitu informasi atau pengalaman masa lalu akan memberikan stimulus dan mempengaruhi kognisi (alam pikiran) yang memungkinkan terjadinya persepsi, motivasi dan terbentuknya sikap dan selanjutnya mempengaruhi perilaku yang muncul.

Hal-hal yang dirasa menjadi kekurangan dalam penelitian ini adalah:

1. Tidak dilakukan penelitian lebih mendalam mengenai perbedaan respon persepsi dan sikap, terkait usia dan gender. Pada penelitian selanjutnya dapat dipertimbangkan untuk mengetahui perbedaan persepsi dan sikap dari penggunaan mebel klasik dikarenakan faktor usia dan gender.

2. Peneliti merasa perlu adanya pengkajian lebih lanjut jika variabel tersebut berpengaruh saat berdiri sendiri atau tidak berpengaruh sama sekali bagi penilaian positif persepsi dan sikap konsumen. 


\section{Daftar Pustaka}

4amri. (2020, Oktober 2). Ekspor Industri Furnitur Jatim Menggeliat. Diambil kembali dari Konfirmasitimes.com: https://konfirmasitimes.com/2020/10/02/ekspor-industri-furniturjatim-menggeliat/

Aji, A. W. (2008). MAKNA TANDA DALAM INTERIOR RUANG TAMU: STUDI SEMIOTIKA SISTEM TERTUTUP PADA INTERIOR RUANG TAMU LIMA STATUS SOSIAL DI YOGYAKARTA. Lintas Ruang, 33-44.

Ambrose, G., \& Harris, P. (2009). Basics Design 08: Design Thinking. New York: Bloomsburry Publishing.

Chen, H.-B., Yeh, S.-S., \& Huan, T. C. (2014). Nostalgic Emotion, Experiental Value, Brand Image, and Consumption Intentions of Costumers of Nostalgic - Themed Restaurants, Journal of Business Research, 354-360.

Dewi, R. S. (2013). Peran Elemen-Elemen Penggubah Desain Interior Yang Bersumber Dari Unsur-Unsur Alam Dalam Wujud Natural Guna Meningkatkan Minat Berkunjung Kembali Di Mal. Bandung: Perpustakaan ITB.

Halim, D. (2005). Psikologi Arsitektur. Jakarta: Grasindo.

Hidjaz, T. (2011). Interaksi Psiko-Sosial di Ruang Interior. Bandung: Itenas.

Kilmer, R., \& Kilmer, W. O. (2014). Designing Interiors. New Jersey: John Wiley \& Sons.

Laseau, P. (2001). Graphic Thinking for Architects \& Designers. New Jersey: John Wiley \& Sons.

Lathiyfah, S. P., Antariksa, \& Noviani , S. (2010). POLA TATA RUANG DALAM RUMAH TINGGAL MASA KOLONIAL DI KIDUL DALEM MALANG. Arsitektur e-jurnal, 4053.

Laurens, J. M. (2005). Arsitektur dan Perilaku Manusia. Jakarta: Grasindo.

Pambudi, J. A. (2017). Studi Semiotika Interior Ruang Tamu Pada Rumah Tinggal Abdi Dalem Keraton Yogyakarta. Yogyakarta: UPT Perpustakaan ISI Yogyakarta.

Purnomo, H., Irawati, R. H., \& Melati. (2010). Menunggang badai: untaian kehidupan, tradisi dan kreasi aktor mebel Jepara. Bogor: CIFOR. Bogor: CIFOR.

Rahma, M. S. (2017). Pengaruh Elemen Interior Restoran terhadap Pengalaman Nostalgia Konsumen. Jurnal Visual Art \& Desain, 67-86.

Rechavi, T. B. (2009). A room for living: Private and public aspects in the experienceof the living room. Journal of Environmental Psychology, 133-143.

Rutherford, J., \& Shaw, E. H. (2011). What Was Old Is New Again: The History of Nostalgia as a Buying Motive in Consumption Behaviour. 15th Biennial Conference on Historical Analysis and Research in Marketing (CHARM) (hal. 157-166). New York: Charm Proceedings.

S, L. (2012). Analisis faktor- faktor gaya hidup dan pengaruhnya terhadap pembelian rumah sehat sederhana (studi pada pelanggan perumahan puri dinar mas pt. Ajisaka di semarang). Jurnal administrasi bisnis, 12-24.

Setiawan, H. B. (2014). Arsitektur Lingkungan dan Perilaku: Pengantar ke Teori, Metodologi dan Aplikasi. Yogyakarta: Gadjah Mada University Press. 
Sitorus, R. (2015, September 10). Bisnis Restorasi Furnitur Lawas Manfaatkan Tren Gaya Retro. kembali dari Bisnis.com: https://entrepreneur.bisnis.com/read/20150910/263/471197/bisnis-restorasi-furniturlawas-manfaatkan-tren-gaya-retro

Snyder, J. C., \& Catanese, A. J. (1989). Pengantar Arsitektur. Jakarta: Erlangga.

Trumansyahjaya, K. (2015). Pemilihan Model Perabot Pada Ruang Dalam Rumah Tinggal Sederhana (Studi Kasus Rumah Tipe 36, 45, 54). Jurnal Radial, 174-180.

Wicaksono, A. A., \& Tisnawati, E. (2014). Teori Interior. Jakarta: Griya Kreasi.

Wukir, I. P., \& Sugiyanto. (2010). Estetika Meja Tamu Gaya Modern sebagai Pelengkap Ruang Tamu. Jurnal Disprotek, 51-61. 
Lintas Ruang: Jurnal Pengetahuan \& Perancangan Desain Interior | Vol.8 No.1 2020 | Hal 31-41 